317. 平均台正勒のフイルム分析

厷島○真田 栄子，吉原 博之

I. 研究目的 体操競技平均台规定問題の実施に於け る時間的，空間的構造の研究.

II. 研究対魚 全日本体操競技選手権大会に出場し， 1966年ドルムント世界選手権大会平均台規定問題を来 施した選手 13 名（9.1〜9.6 までの上群 5 名と8.1〜8.5 までの下群 8 名).

III. 研究方法 1965 年 11 月 26 日京都市体有館で行 われた全日本体操競技遗手権大会の平均台規定問題を送 り速度 16 コマで 8 ミリ撮影しフフイム分析を行つた。 フイルム分析に際し，特定動作を選択する規準は，平均 台規定問題集と 1964 年 女子採点規則及び マイネル著運 動学以上三つの文献により，運動の流れ, 正確性, リズ ム, 調和, 動作の違いの 5 項目を特定動作の比較項目と した.

\section{IV. 桔果と考来}

a 運動の流れ ある技から他の技への移行に於いて 平均を失つたり，理由のない停止を行つた平均回数か， 上群 1.2 回, 下群 3 回であり，上群は，良い運動の流れ をしている.

b 運動の正確性 例えば測定 項目中の倒立 コマ数
は，上群 53.6 コマ，下群 29.9 コマであり，上群は，規 定問題集の代表的欠点及び一般過失が少なく正確かつ安 全な実施を行つている.この実施こそ運動構造の変化を 促し，独創的な技を生み出す要因である.

c 運動のリズム 例えば湘定項目中の継ぎの演技で ある助走して踏み込久着台までのコマ数は上群 29.8 コ マ，下群 36.0 コマであり，上群怯，合目的的な時間的 分割をなし良い運動のリズムを作つている。

d 動作の違い 解説文「両腕は平行に前上一斜めに 上げる」に対し，腕の状態は，A斜め前上と，B真上の 2 つ火分類でき，上群A 3，B 2, 下群 A 3，B 5で上下 群とも各自の能力に 合わせ， 2 個性的な 演技をしてい る.

e 運動の調和 上群は，運動の流れ，正確性，リズ ムに優れているという事から，良い運動の調和をしてい る.

\section{V.むすび}

上群は運動の流れ，正確性、リズム，調和に優れてい た。以上規定問題には規定された演技を正確かつ安全に 実施する側面があり，この側面こそ規定問題の特質を示 している. 又一方個性的，独創的演技も実施している.

\section{8. 利郝の研究}

\section{京都教育大学附属高等学校}

○藤田 一郎, 川北 智世

サッカー選手が両脚に同等の機能を䚚えることが必要 であることは明確なことである，そこで，その基本的な 問題として利脚について調査実験をした。

〔方法〕（1）利脚の実態について，一般高校 1 年生男 子 101 名，高校サッカー選手 123 名に対して走巾跳，ボ ールコントロールの使用脚を調査.（2）サツカー選手 （123名）の利脚と逆脚のスキルテスト実施.（3）逆脚 練習効果の実験.（A）一ボールつきー1日10回，30 日間連続練習を逆脚の又使用租，両脚自由使用組，利脚 のみ使用組, 各 2 名について夷施.（B）一走脁一利 脚，逆脚夫々に対して1日 3 回，20日間湘定実施.

〔結果〕（1）については，利㑢の概念涀定が明確でな いか，従来の研究の多くは“強さ”にそれを求めている が，私はそれを“巧緻性”に求め，ボールコントロール のやりやすい脚とした．サッカー選手と一般高校生の間 に顕著な差はなく，右脚利きが93\%であり，利腕の器用 さとその出現率を関連させて 妥当であると考える. については，サッカー選手の使用脚のスキルの差に打い
て利用の実態を把握した（3）については，逆脚は利脚 とほぼ同型の発達曲線を示すことから，使用頗度を同じ にすれば逆脚機能が利脚と同等の発達をとげることが判 明した. しかし，スキル，筋力の上で逆脚が利脚と同等 な発達をとげても，依然として利脚を钼念的に従来の使 用脚とすることに注目し，利㑢を形成している要因に， 生理学的要因に起因する心理学的要因（観念的）と力学 的要因（スキル）とがあるものと考える.

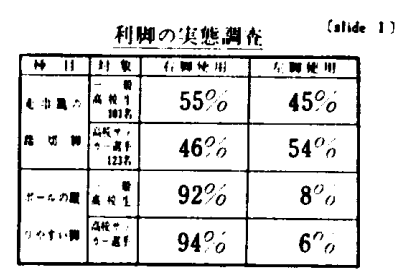

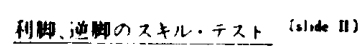

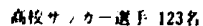

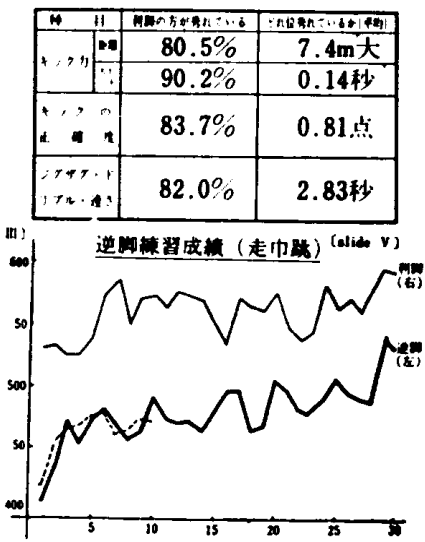

